\title{
Oil, Gas and Energy Business under One Belt One Road Strategic Context
}

\section{Md. Nazirul Islam Sarker ${ }^{1}$, Md. Altab Hossin², Yinxiao Hua ${ }^{3}$, Md. Kamruzzaman Sarkar4, Nitin Kumar ${ }^{5}$}

${ }^{1}$ School of Public Administration, Sichuan University, Chengdu, China

${ }^{2}$ Department of Management Science and Engineering, University of Electronic Science and Technology of China, Chengdu, China

${ }^{3}$ School of Automation Engineering, University of Electronic Science and Technology of China, Chengdu, China

${ }^{4}$ Department of Zoology, National University, Gazipur, Bangladesh

${ }^{5}$ Business School, Sichuan University, Chengdu, China

Email: sarker.scu@yahoo.com

How to cite this paper: Sarker, Md.N.I., Hossin, Md.A., Hua, Y.X., Sarkar, Md.K. and Kumar, N. (2018) Oil, Gas and Energy Business under One Belt One Road Strategic Context. Open Journal of Social Sciences, 6, 119-134.

https://doi.org/10.4236/jss.2018.64011

Received: March 18, 2018

Accepted: April 20, 2018

Published: April 23, 2018

Copyright $\odot 2018$ by authors and Scientific Research Publishing Inc. This work is licensed under the Creative Commons Attribution International License (CC BY 4.0).

http://creativecommons.org/licenses/by/4.0/

\begin{abstract}
One Belt One Road (OBOR) Initiative of China is a mega and historical project which facilitates international oil, gas and energy trade and connects people over the world. This article examines the oil, gas, and energy business status under OBOR. It also explores the risk associated with oil, gas and energy business under OBOR initiative of China. The article used secondary sources extensively. The article reveals that China is the top-level energy importing country and the strategy of OBOR is favorable for oil, gas and energy business for all partner countries of OBOR. It also explores the potential risk for oil, gas and energy business under OBOR like political risk, economic risk, investment environment, resource potential, environmental constraints and Chinese factors which can be minimized by using two risk free economic corridors viz. China-Pakistan Corridor (CPEC) and Myanmar-China oil pipeline. The article suggests that a strong initiative should be taken by the government to implement OBOR strategy for creating favorable investment opportunities in China especially for Middle Eastern countries like Saudi Arabia, Russia, Kazakhstan, and Pakistan.
\end{abstract}

\section{Keywords}

OBOR, One Belt One Road, Energy, Global Economy, International Trade

\section{Introduction}

China is getting benefit from globalization and trade liberalization by making 
world largest manufacturing center [1]. But China faces a slowdown in the economy due to global and inter-regional trade [2]. Chinese President Xi Jinping proposed a historical initiative for connecting the world through "Silk Road Economic Belt" and "21st Century Maritime Silk Road". Both of the Initiatives are known as One Belt One Road (OBOR). Recently it is called Belt and Road Initiative (BRI). The major objective of this initiative is to maintain global trade, realizing development path. This initiative connects different countries and increases cooperation and mutual benefits and promoting global economic system through strengthening the relationship. It also attracts its partner countries, regions and global attention [3]. Already 65 nations are agreed to extend their cooperation under OBOR. One of the main items of this cooperation is energy. Energy is the key item for every country. China's energy consumption and demand are increasing day by day. So, China's core energy strategy is very favorable for foreign energy investment in China. OBOR increases this oil, gas and other energy investment opportunity to China and mutual benefits [4]. It also creates a new platform for overseas oil, regional stability, and energy security. So, it is a big opportunity for the partner countries of OBOR. The OBOR initiative already achieved its partnership from 5 countries of Central Asia, Mongolia from East Asia, 8 countries from South Asia, 10 ASEAN countries, 18 from West Asia and Northern Africa, 7 from Commonwealth of the Independent States and 16 from Middle Eastern Europe [5]. According to a statistic of EIA, 58.8\% oil, $79.9 \%$ natural gas and $54.0 \%$ coal of the world's total energy is under the hand of OBOR partner countries [6]. So, energy cooperation among the partner countries helps to stable and ensure energy security and trading under OBOR partner countries. A continuous and stable energy supply claims energy investment from energy demanding countries. Global energy investment is passed more than $\$ 1.6$ trillion by 2035 for mining, transportation, and refinement of fossil fuel energy [7]. The emerging countries will get this facility up to two-third portion. Due to increasing demand, the investment of energy areas and regions will be increased and expanded from China to different parts of Asia, Latin America, and Africa. One of the major factors is the risk associated with overseas energy investment. The main energy exporting countries are from Middle East, Russia, and Central Asia. Energy trading becomes in high risks due to the singular economic system, political risk, and lack of financial technology [5]. Therefore, the energy business is one of the prime concerns of OBOR for stimulating the future energy business development (Figure 1).

Now the Chinese authorities are very aware of energy business to overcome the weakness of foreign trade policies and transnational agreement [9]. Therefore, Chinese authority revived the old Silk Road by introducing New Economic Silk Belt which connects China to Europe through Central and Western Asia. On the other hand, the $21^{\text {st }}$ Century Maritime Silk Road connects China and Southeast Asian Countries to Europe and Africa. These two initiatives are jointly known as One Belt One Road (OBOR). One of the primary objectives is to support paradigm shift to regional and foreign trade for improving networks of 


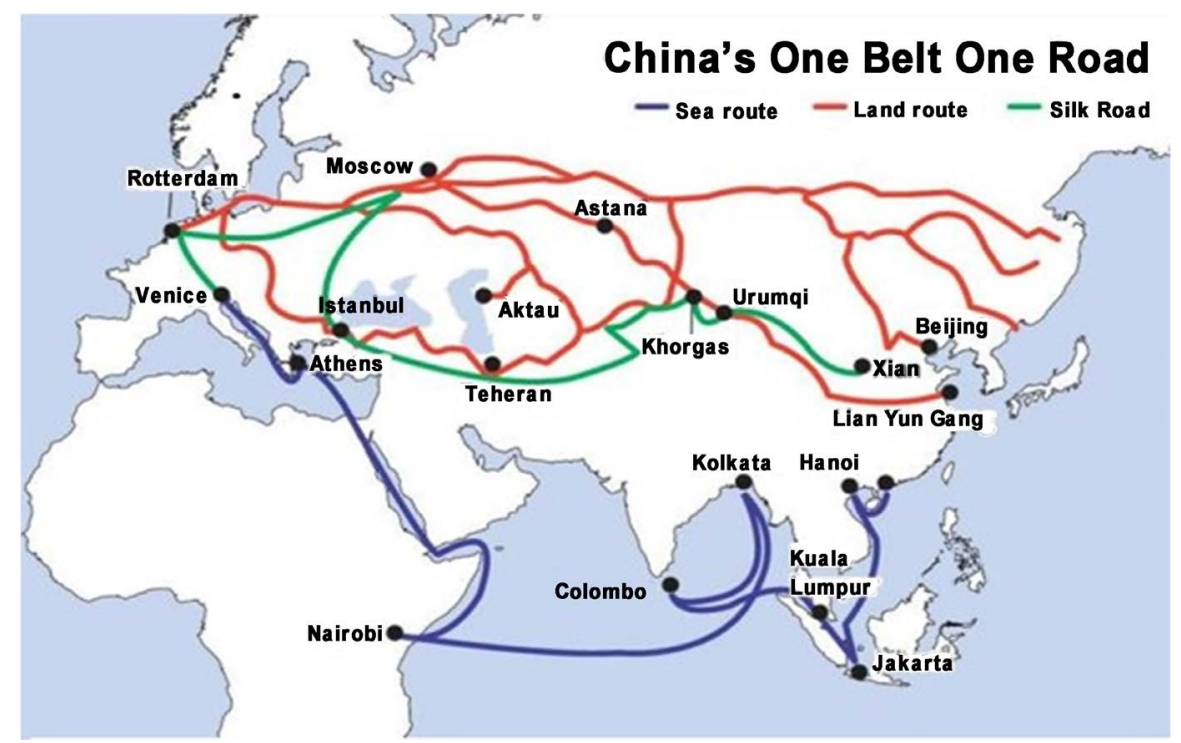

Figure 1. One Belt One Road (OBOR) business network. Source: Sheu and Kundu [8].

logistics and transportation with infrastructure and strategy development through six economic corridors [8]. Political and international trade agreement decision sometime changes the activity of logistics and transportation. Consequently, financial losses may occur in logistic distribution flow networks due to high risk the traders adept new spatial structure [10]. Therefore, international logistic network especially which is dealing energy trading should be restructured in the perspective of spatial-temporal interactions.

This article contributes to the existing literature by exploring risk free energy business and opening clear understanding about the energy business under OBOR partner countries [11]. It also added to the literature by exploring possible risks of energy business under OBOR and initiatives of China for greater cooperation with others [12]. The second section describes methodology of the study. Third and fourth section explains review of related literature and energy supply chain respectively. The fifth and sixth sections depict possible risks and recommendations. The final sections conclude the article.

\section{Methodology}

\subsection{Research Design}

Energy business prospect, risk and challenges under OBOR is explored through an extensive review of the literature [13]. The research is descriptive in nature using some indicators of international energy business. It mainly focuses on oil, gas and energy business under OBOR strategic context and explain the possible challenges with some recommendations for energy security among partner countries of OBOR initiative.

\subsection{Sources of Data}

The article uses secondary sources extensively related to energy business, chal- 
lenges and opportunities of international energy trade, OBOR facilities for energy trade and future energy security at global level. The latest information has been included for a better recommendation for future energy business under OBOR. All the partner countries and economic corridor and logistic distribution have been considered on this study but it is also applicable for regional energy trade.

\subsection{Search Strategy}

The study has been extensively searched some renowned databases like google scholar, a web of science, science direct, Springer link website using important keywords like "oil, gas, risk, challenges, energy trade, one belt one road, and China for getting desired data [14]. The data collection and analysis for this study has been done from November to December 2017. Literature reviews are a significant part of the development of a field [15]. They offer the opportunity to synthesize and reflect on previous research, and thus providing secure grounding for the advancement of knowledge [16]. By maintaining systematic procedure, this study has been analyzed finally 59 documents including books, journal articles and survey report on energy trade (Figure 2).

\subsection{Data Analysis}

Data has been analyzed from different perspectives of energy trading like rout of logistic distribution, OBOR strategy, economic corridors, possible risks and challenges, future opportunities, energy security and regional energy business.

\section{Review of Related Work}

Global supply chain is a major concept of global business. There is a competition between firms in terms of products, quality, and supply chain among the partner countries of OBOR due to progress of technology and globalization [17]. Modern and improved policies and holistic network design are able to tackle the risk and uncertainties related to logistic supply chain in global business operation [18]. Decision making is important for global trade in terms of warehousing, location, inventory management, management of distribution and transportation, proper coordination and contracts among traders [19]. Global energy trading is improving due to the improvement of information technology but physical flows of the product through logistic companies need to be smooth [20]. However, internal and domestic business can easily handle than global trade because of bearing some risks and uncertainties. Global energy trade is affected by currency exchange rate, economic and geographical constraints and political instability, taxation, entry-exit regulation, transfer prices, insecurity of network and terrorism [21]. However, economies of scale are another major factor of firm's decision making in terms of location and distribution of product [22]. There are some other factors of global energy trade which include buyer, seller, policy maker and service providers. These factors should be considered for global 


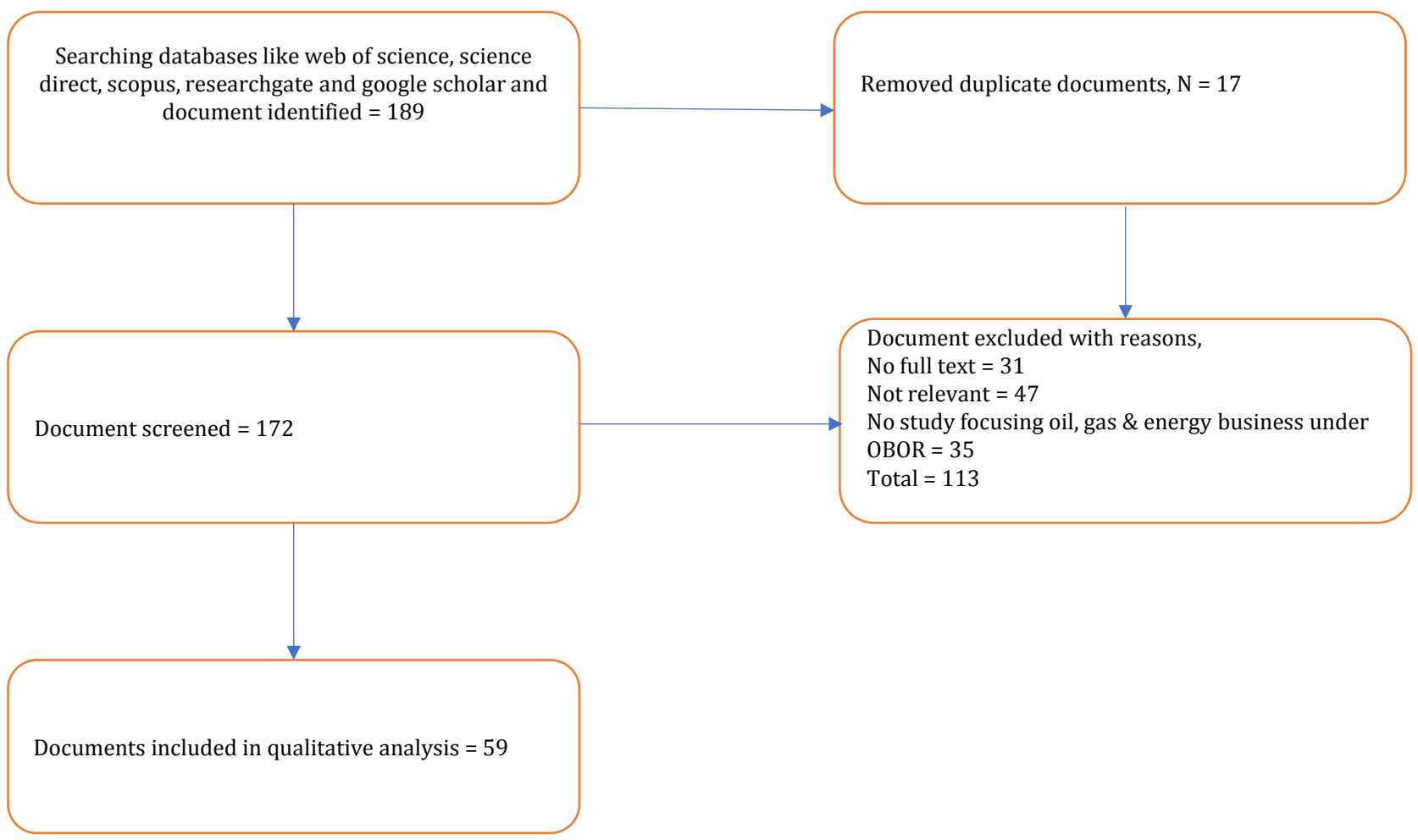

Figure 2. Flow diagram of study selection.

energy trade. The OBOR initiative gives a big platform for the global energy business by minimizing risks and uncertainties [23].

Zheng [24] analyzed the uncertainties on investment and prices of natural gas fuel for a competitive market and conclude that energy business has a great potential in the global market. Liedtke [25] also mentioned that the oil investment decision of China is favorable for OBOR partner countries. Jianjun et al. [26] determined China's subsidy on the uncertainty of coal business and conclude that it is favorable for the energy business. Some other researchers also analyzed the energy investment decision in terms of carbon emission and clean renewable energy development mechanism. political, social and financial risks are the major risks in overseas investment [12]. Aloui et al. [27] used some indicators for these risks. The country-based risk is measured by Tang [12] through developing environmental risk awareness model and mentioned three environmental risks viz. industrial environmental risks, macro-environmental risks, and corporate-micro-environmental risks. But Kang, Ratti, \& Vespignani [28] considered political, operational, economic and social aspects for making comprehensive risk index. Liedtke [25] measured the risk of crude oil exporting countries by decomposition hybrid approach and conclude that a smooth initiative is necessary for global crude oil business. The summary of the literature review is as follows (Table 1).

The extensive literature review shows that most of the research is done only investment issues related to operational risk and uncertainty. Only a few studies 
Table 1. Major research on low carbon economy.

\begin{tabular}{|c|c|c|}
\hline $\begin{array}{l}\text { Researcher \& } \\
\text { duration }\end{array}$ & Summary of finding & Journal or source \\
\hline Wang et al., 2013 [29] & $\begin{array}{l}\text { Gas production of China will only be } 164.6 \mathrm{bcm} \text { in } \\
2020 \text { which is lower than forecast demand. }\end{array}$ & Energy Policy \\
\hline $\begin{array}{l}\text { Sinogasenergy, } \\
2016[30]\end{array}$ & $\begin{array}{l}\text { The energy business is inherently subject to business, } \\
\text { economic, competitive, political and social } \\
\text { uncertainties and contingencies. }\end{array}$ & Sinogas energy \\
\hline $\mathrm{Wu}, 2008[31]$ & $\begin{array}{l}\text { "Going out" has become part of the overall } \\
\text { investment strategy for every state oil company in } \\
\text { China. }\end{array}$ & $\begin{array}{l}\text { Oil and Gas Energy } \\
\text { Law }\end{array}$ \\
\hline $\begin{array}{l}\text { China Energy Group, } \\
2014[32]\end{array}$ & $\begin{array}{l}\text { China consumed for } 20 \% \text { of global energy. Energy } \\
\text { grew } 51 \% \text { percent as fast as GDP. }\end{array}$ & $\begin{array}{l}\text { Lawrence Berkeley } \\
\text { National Laboratory }\end{array}$ \\
\hline $\begin{array}{l}\text { Cunningham, } 2015 \\
{[2]}\end{array}$ & $\begin{array}{l}\text { Chinese outward foreign direct investment (ODI) } \\
\text { ranked fifth in the world in } 2014 \text { and accounted for } \\
5.7 \text { percent of the global total, just ahead of Russia. }\end{array}$ & $\begin{array}{l}\text { Global Economic } \\
\text { Governance Initiative } \\
\text { Working Paper }\end{array}$ \\
\hline $\begin{array}{l}\text { Edwards, Ishaq, \& } \\
\text { Johnsen, } 2011[33]\end{array}$ & $\begin{array}{l}\text { Technology is the most important force to increase } \\
\text { the supply of more challenging oil and gas and } \\
\text { mitigate the environmental impact of energy } \\
\text { production and consumption. }\end{array}$ & $\begin{array}{l}\text { IBM Global Business } \\
\text { Services, Executive } \\
\text { Report }\end{array}$ \\
\hline Wang, 2016 [11] & $\begin{array}{l}\text { China now has reserve/production ratios of } 11.9 \text { and } \\
30.4 \text { for crude oil and natural gas. }\end{array}$ & $\begin{array}{l}\text { The Oil \& Gas } \\
\text { Conference, Denver, } \\
\text { Colorado }\end{array}$ \\
\hline Dent, 2015 [34] & $\begin{array}{l}\text { China faces serious energy security challenges, as } \\
\text { burgeoning industrial-based development and rising } \\
\text { material demands of business and society. }\end{array}$ & $\begin{array}{c}\text { Asia Pacific Business } \\
\text { Review }\end{array}$ \\
\hline $\begin{array}{l}\text { Thomson \& Boey, } \\
2015 \text { [35] }\end{array}$ & $\begin{array}{l}\text { The role of oil and gas in China 's energy strategy are } \\
\text { set to remain very significant over the next } 20 \text { years. }\end{array}$ & $\begin{array}{c}\text { Asia Pacific Business } \\
\text { Review }\end{array}$ \\
\hline $\begin{array}{l}\text { Wang, Zhu, \& Wang, } \\
2017[36]\end{array}$ & $\begin{array}{l}\text { Shocks of oil supply havesignificant negative impacts } \\
\text { on China 's export duration, while aggregate demand } \\
\text { shocks have a significantly positive impact } \\
\text { on China's export. }\end{array}$ & Energy \\
\hline Aloui et al., 2016 [27] & $\begin{array}{l}\text { Higher uncertainty increases crude-oil returns only } \\
\text { during certain periods of time. }\end{array}$ & Energy Economics \\
\hline Shao et al., 2017 [10] & $\begin{array}{l}\text { Crude oil import of China is associated with } \\
\text { exporting country's supply, demand, and price and } \\
\text { its bilateral trade relationships. }\end{array}$ & Energy Policy \\
\hline Sun et al., 2017 [19] & $\begin{array}{l}\text { The energy exporting countries of OBOR are trying } \\
\text { to reduce oil and gas export dependence and to } \\
\text { extend their industrial chain to promote economic } \\
\text { growth. }\end{array}$ & IAEE Singapore 2017 \\
\hline $\begin{array}{l}\text { Kang, Perez de } \\
\text { Gracia, \& Ratti, } \\
\quad 2017[37]\end{array}$ & $\begin{array}{l}\text { Demand-side shock has a positive effect on the } \\
\text { return of oil and gas companies on average, whereas } \\
\text { shocks to policy uncertainty have a negative effect on } \\
\text { the return. }\end{array}$ & $\begin{array}{l}\text { Journal of } \\
\text { International Money } \\
\text { and Finance }\end{array}$ \\
\hline Zhang et al. 2017 [38] & $\begin{array}{l}\text { Prices of natural gas increases lead to an increase in } \\
\text { the consumer price index (CPI) and lead to } \\
\text { reductions in GDP. }\end{array}$ & $\begin{array}{l}\text { Journal of Cleaner } \\
\text { Production }\end{array}$ \\
\hline Zhang et al., 2017 [39] & $\begin{array}{l}\text { The seasonal peak-shaving issues are increasingly } \\
\text { prominent with the rapid development of natural gas } \\
\text { industry in China. }\end{array}$ & $\begin{array}{l}\text { Natural Gas } \\
\text { Industry B }\end{array}$ \\
\hline $\begin{array}{l}\text { Jianjun et al., } 2016 \\
\text { [26] }\end{array}$ & $\begin{array}{l}\text { The global oil prices have a significant impact on } \\
\text { China s oil and gas industry system and the national } \\
\text { energy security. }\end{array}$ & $\begin{array}{l}\text { Natural Gas } \\
\text { Industry B }\end{array}$ \\
\hline
\end{tabular}




\section{Continued}

\begin{tabular}{|c|c|c|}
\hline Zheng, 2017 [24] & $\begin{array}{l}\text { Oil security is the major concern of China's energy } \\
\text { policy due to the no effective substitute oil and the } \\
\text { heavy reliance on internationally imported crude oil. }\end{array}$ & $\begin{array}{l}\text { American Journal of } \\
\text { Industrial and } \\
\text { Business } \\
\text { Management }\end{array}$ \\
\hline Liu \& Ma, 2016 [40] & $\begin{array}{l}\text { The low oil price has resulted in business } \\
\text { performance decline of oil and gas companies. }\end{array}$ & $\begin{array}{l}\text { Natural Gas Industry } \\
\text { B }\end{array}$ \\
\hline $\begin{array}{l}\text { Li, Cheng, \& Yang, } \\
2015[41]\end{array}$ & $\begin{array}{l}\text { The oil industry is mainly influenced by domestic } \\
\text { demand shock, while plays the dominant factor of } \\
\text { the returns of oil exploitation and oil sales industries. }\end{array}$ & Energy Procedia \\
\hline $\mathrm{Wu}, 2014$ [9] & $\begin{array}{l}\text { China is now a net importer of oil, natural gas, and } \\
\text { coal. }\end{array}$ & Energy Policy \\
\hline Jiang et al. 2016 [42] & $\begin{array}{l}\text { The low-cost strategy will be indispensable to oil and } \\
\text { gas business. }\end{array}$ & $\begin{array}{l}\text { Natural Gas } \\
\text { Industry B }\end{array}$ \\
\hline Yang et al., 2016 [4] & $\begin{array}{l}\text { China is the world's largest emitter of greenhouse } \\
\text { gases, sulfur dioxide, nitrogen oxides and particular } \\
\text { matter. }\end{array}$ & $\begin{array}{l}\text { Environmental } \\
\text { Development }\end{array}$ \\
\hline $\begin{array}{c}\text { Yang, Tong, \& Ou, } \\
2014[43]\end{array}$ & $\begin{array}{l}\text { If China's energy consuming sectors adopted } \\
\text { appropriate energy-saving technologies, total } \\
\text { energy-savings would be } 200 \text { million, } 450 \text { million, } \\
650 \text { million and } 800 \text { million tons of standard coal in } \\
2015,2020,2025 \text { and } 2030 \text {, respectively. }\end{array}$ & $\begin{array}{l}\text { Open Journal of } \\
\text { Energy Efficiency }\end{array}$ \\
\hline Pan et al., 2017 [21] & $\begin{array}{l}\text { Over-capacity in China's refining industry is at the } \\
\text { severest level. The measurement reveals the } \\
\text { driven-force of over-capacity from supply chain } \\
\text { perspective and demonstrates a quantitative method } \\
\text { to figure out the proper capacity of energy supply } \\
\text { industry. }\end{array}$ & Applied Energy \\
\hline $\begin{array}{l}\text { Burger \& Luke, } 2017 \\
\qquad[44]\end{array}$ & $\begin{array}{l}\text { Continued cost declines, technological innovation, } \\
\text { and changing policy and regulatory landscapes mean } \\
\text { the business models of tomorrow will likely look } \\
\text { very different than the business models of today. }\end{array}$ & Energy Policy \\
\hline Tang et al., 2018 [12] & $\begin{array}{l}\text { The changes in tax policies have become the } \\
\text { important factors of risk in oil and gas investment. }\end{array}$ & $\begin{array}{l}\text { Journal of Petroleum } \\
\text { Science and } \\
\text { Engineering }\end{array}$ \\
\hline Duan et al., 2018 [5] & $\begin{array}{l}\text { Overseas energy investment as an effective way of } \\
\text { securing energy supply is being favored by the } \\
\text { world's leading energy-consuming countries. }\end{array}$ & $\begin{array}{l}\text { Journal of Cleaner } \\
\text { Production }\end{array}$ \\
\hline
\end{tabular}

have been done on the prospect of energy business under OBOR strategic context. This peace of study will fill up the gap of the knowledge of literature by exploring the status, potential opportunities and possible challenges of energy business under OBOR initiative.

\section{Chinese Oil, Gas and Energy Supply Chain in OBOR Context}

The demand for energy in China is increasing rapidly due to its fastest economic development and industrialization. The major part of China's energy security plan is to access to sufficient oil supplies which are also a part of China's national security [24]. More than 11 million barrels per day oil is the requirement for consumption in China which leads China to become atop most oil importer in 
2014 [6]. The oil import becomes double at 57\% in 2014 from $30 \%$ in 2000 which creates a major challenge for the Chinese government in the aspect of oil security. The main three challenges of oil importing countries are facility dependence, source dependence and transit dependence [45]. Now China imports oil from more than 15 countries [46] of which Saudi Arabia, Iran, Russia, Angola, Iraq, Oman, and Pakistan are the main suppliers [6]. The recent trend of the demand for various energy products of China is shown in Table 2.

The transportation network for oil import is an area to maintain security since the exporting countries are fixed. Usually, oil tanker and pipelines are used to import oil from oil exporting countries to China (Figure 3). So, the way is used for importing about $83 \%$ oil in China of which strait of Malacca is used for transportation rout for $80 \%$ oil since it is a geopolitically dispute zone [24].

A single rout is necessary for China to import oil, and other energy items and minimize the risk and challenges. According to Shaikh et al. [47], one of the major strategies for minimizing risk is route diversification. It is a great opportunity that OBOR initiative provides this diversification through various corridors like China-Pakistan Corridor (CPEC) and Myanmar-China oil pipeline. The rout of Malacca can easily avoid by using these two routes. The OBOR logistic network facilitates to use rout diversification for administering oil freight flow and minimizing risks and challenges (Figure 4).

OBOR initiative helps china for diversifying the routes of transportation from Russian and Iranian oil and gas through linking with pipeline networks from Russia and Central Asia. It has been strengthening to Gwadar coast of Pakistan and coastal Myanmar to Yunnan, China through pipeline connection which can reduce the vulnerability of energy supply and promote energy security. The proposed economic corridor will reduce cost and time for energy transportation which will promote business.

\section{Risk Associated with Oil, Gas and Energy Business}

There are some challenges and risk also associated with oil, gas and other energy business in the perspective of global tradeas international trade always bears

Table 2. Demand for various energy products of China (thousand barrels per day).

\begin{tabular}{cccccccc}
\hline \multirow{2}{*}{ Products } & \multicolumn{3}{c}{ Demand } & \multicolumn{3}{c}{$\begin{array}{c}\text { Annual change } \\
(\mathrm{kb} / \mathrm{d})\end{array}$} & \multicolumn{2}{c}{$\begin{array}{c}\text { Annual change } \\
(\%)\end{array}$} \\
\cline { 2 - 8 } & 2015 & 2016 & 2017 & 2016 & 2017 & 2016 & 2017 \\
\hline LPG \& Ethane & 1114 & 1273 & 1353 & 159 & 80 & 14.3 & 6.3 \\
Naphtha & 994 & 1063 & 1088 & 69 & 25 & 6.9 & 2.4 \\
Motor Gasoline & 2526 & 2596 & 2728 & 71 & 132 & 2.8 & 5.1 \\
Jet Fuel \& Kerosene & 620 & 652 & 686 & 32 & 33 & 5.2 & 5.1 \\
Gas/Diesel oil & 3388 & 3305 & 3290 & -83 & -15 & -2.5 & -0.4 \\
Residual fuel oil & 317 & 191 & 140 & -125 & -51 & -39.6 & -26.9 \\
Other products & 2478 & 2532 & 2574 & 54 & 42 & 2.2 & 1.7 \\
Total products & 11436 & 11613 & 11859 & 177 & 246 & 1.5 & 2.1 \\
\hline
\end{tabular}

Source: BP Statistical Review of World Energy [47]. 


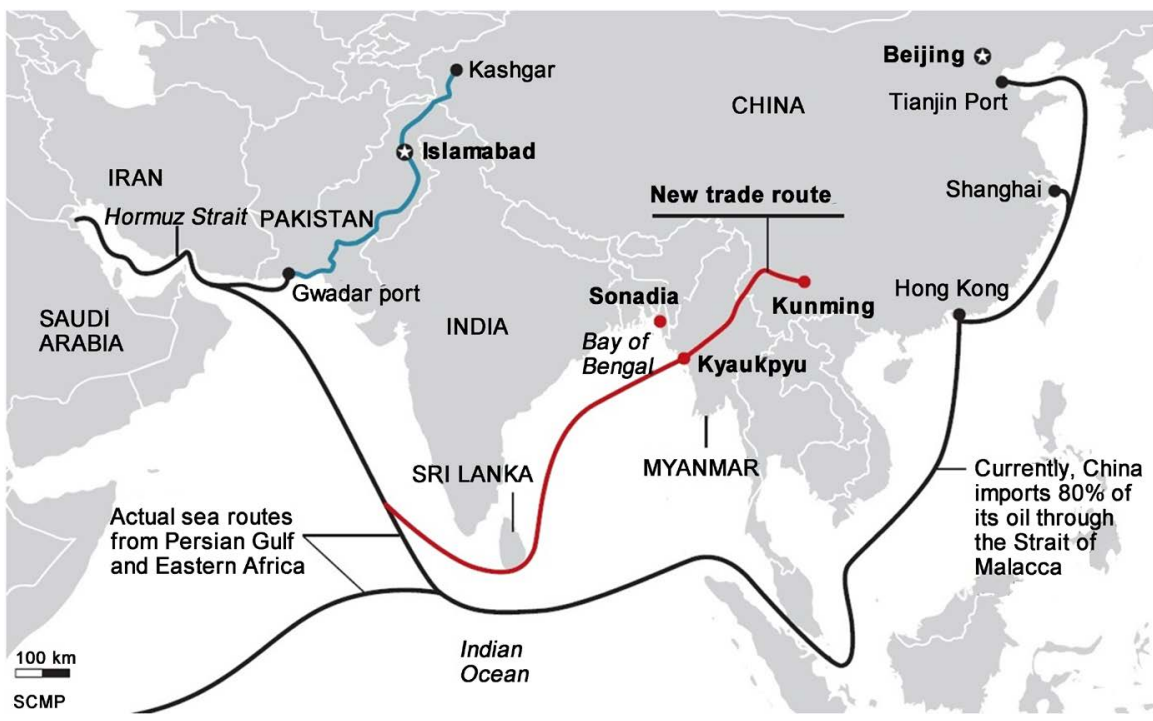

Figure 3. Chinese oil supply chain network under OBOR. Source: Adapted from Sheu and Kundu [8].

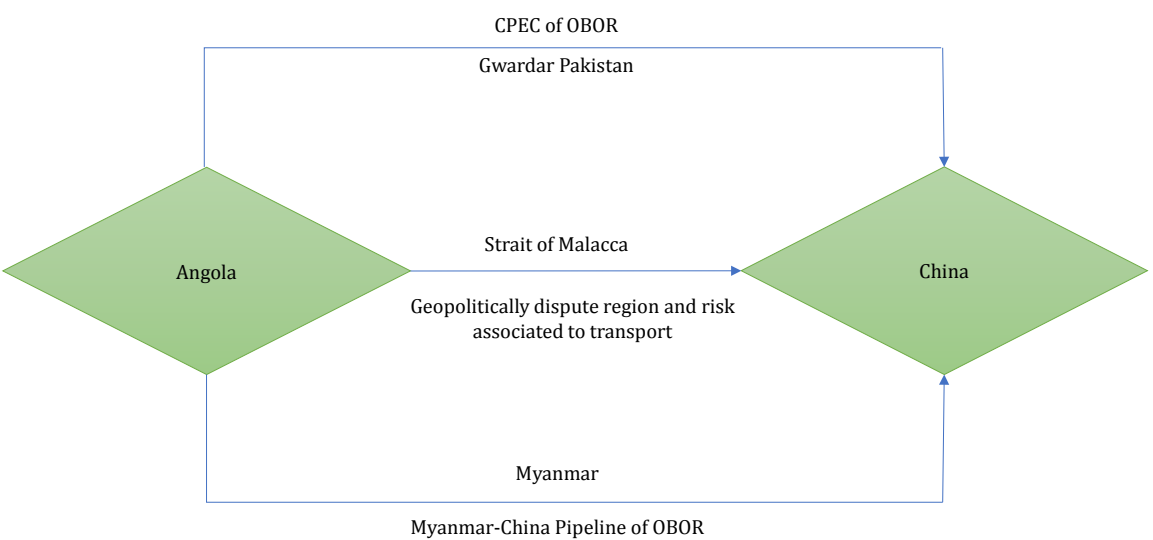

Figure 4. Risk-free energy transport routs under OBOR.

some risks and challenges in import and export. This study finds out six dimensions of risks viz. political risk, economic risk, investment risk, resource potential, environmental risk and Chinese factor. The six dimensions of risks focused some indicators of risk for better evaluation (Table 3).

\subsection{Political Risk}

Political stability is essential for international trade. Political instability invites strike, procession, blockade, and other damaging activities which are very harmful to running as mooth business and bears great risks [5]. A safe investment requires low political risk and political stability for international trade. The stability of government has a great effect on foreign company's management and investment [45]. The unstable political condition has a bad effect on the willingness of the foreign company for investment. This study identified some major political risks like political instability, corruption, extortion, the conflict between domestic political parties, clash with other external countries, non-accountability 
Table 3. China's overseas energy investment risk evaluation indicator system.

\begin{tabular}{|c|c|}
\hline Dimension & Indicators \\
\hline Political risk & $\begin{array}{c}\text { Government stability } \\
\text { Internal conflict } \\
\text { External conflict } \\
\text { Corruption } \\
\text { Law and order } \\
\text { Democratic accountability }\end{array}$ \\
\hline Economic risk & $\begin{array}{c}\text { GDP per capita } \\
\text { Real GDP growth } \\
\text { Annual inflation rate } \\
\text { Budget balance as a percentage of GDP } \\
\text { Foreign debt as a percentage of GDP } \\
\text { Exchange rate stability Starting }\end{array}$ \\
\hline Investment risk & $\begin{array}{l}\text { Starting a business } \\
\text { Dealing with construction permits } \\
\text { Getting electricity } \\
\text { Paying taxes } \\
\text { Enforcing contracts } \\
\text { Resolving insolvency }\end{array}$ \\
\hline Resource potential risk & $\begin{array}{c}\text { Total oil production } \\
\text { Crude oil proved reserves Dry natural gas production Proved } \\
\text { reserves of natural gas } \\
\text { Crude oil distillation capacity } \\
\text { Total exports of refined petroleum products Carbon }\end{array}$ \\
\hline Environmental risk & $\begin{array}{c}\text { Carbon dioxide emissions } \\
\text { Nitrous oxide emissions } \\
\text { Energy intensity } \\
\text { Carbon dioxide intensity PM2.5 } \\
\text { Forest area (\% of land area) }\end{array}$ \\
\hline Chinese factor risk & $\begin{array}{c}\text { Years of China's diplomatic relations } \\
\text { Outward FDI stock } \\
\text { Value of contracted projects } \\
\text { Persons abroad of contracted projects and labor services Value } \\
\text { of total imports from China } \\
\text { Value of total exports to China }\end{array}$ \\
\hline
\end{tabular}

Source: Duan et al. [5].

of the politicians and poor law and order situation [48]. OBOR facilitates an opportunity for partner countries to reduce the political instability through mutual discussion [37].

\subsection{Investment Risk}

The operational environment of an investor country should be good for doing international trade. A foreign company always expects a favorable investment environment for running the business smoothly. If there is any possibility of investment risk to the investment country, the foreign company will not invest for their business [25]. This study identified some investment risks like investment permit from government agencies, tax and tariffs, construction and electricity permits, logistic support and contract enforcement [40]. OBOR minimizes in- 
vestment risk through mutual discussion facility among various partners for minimizing investment risk [5]. But still, need some clarification from OBOR authority for minimizing future investment risk.

\subsection{Economic Risk}

An investor country should have a strong economic base for running international trade smoothly. A good economic base is a guarantee of return the profit quickly as well as security for a company. So economic risk should be minimized through proper implementation of OBOR strategy [49]. This study identified some economic risks like poor GDP growth rate, poor GDP per capita, excessive inflation, deficit budget, fluctuation of the exchange rate and foreign debt [40]. OBOR initiative minimizes the economic risks through establishing Asian Investment Bank Ltd (AIBL) and facilitating mutual cooperation among partner countries [8].

\subsection{Resource Potential Risk}

The feasibility of an investor country can be easily assessed by measuring their resource potential. The countries which possess more oil, gas, and energy resources have a great resource potential for getting foreign investment [50]. So, resource potential is an indicator to get foreign investment. But still, there are some risks associated with resource potentials like the low capacity of oil production, poor reserve capacity of crude oil, low capacity of production and reserve of natural gas [5].

\subsection{Environmental Risk}

Environmental risk is a prior concern of every nation. Carbon dioxide $\left(\mathrm{CO}_{2}\right)$ emission, greenhouse effect and global warming are the major risk for human civilization. International trade is always conscious about environmental issues. There is a provision for all good investors i.e. the compliance of environmental issues by the business entity [5]. So, international trade requires full compliance of environmental issues from their counterparts. OBOR has a provision regarding environmental issues. Tax and tariff system and macro policy of a country may be influenced by the environmental risks which affect the international oil, gas and energy business and the investment decision of a foreign company [24]. This study has identified some environmental risks like high $\mathrm{CO}_{2}$ emission, high Nitrous Oxide $\left(\mathrm{NO}_{2}\right)$ emissions, the intensity of $\mathrm{CO}_{2}$ and energy, PM25 index and insufficient forest area [37].

\subsection{Chinese Factor Risk}

According to Duan et al. [5], Chinese factor is a major concern for doing business with Chinese companies. The business associated risks are not always same in every country. It is depending on the political ideology, diplomatic attitude, and creditworthiness of the companies of buyer and seller country [51]. OBOR 
initiative provides an opportunity to minimize the Chinese factors for making a better business environment with other partner countries [52]. Actually, OBOR strategy acts as a buffer between the Chinese investor to others oil, gas, and energy exporting countries and vice-versa [53]. This study identified some Chinese factors as diplomatic relationship duration, the total value of export and import, outward foreign direct investment, value and labor of project.

\section{Recommendations}

1) The study finds out two comparatively risk free economic corridors like China-Pakistan economic corridor and Myanmar-China Pipeline which will be more profitable to invest in oil pipeline setting. It is more beneficial for China and other countries for the oil business. It minimizes risk in oil transportation, distribution, and trading.

2) Geographical and political challenges should be minimized by are gular discussion with partner countries of OBOR for energy security.

3) High altitude should be avoided for making future pipeline within OBOR partner countries because it bears vulnerability and risk in energy transportation. The elevation of CPEC transportation network is 15,000 feet which are over 6000 feet above the global highest pipeline. Due to a geopolitical dispute between India and Pakistan, CPEC network is vulnerable to energy business [4]. Vulnerability should be minimized by mutual discussion.

4) Iran to Kazakhstan and Iran to China is another potential route for oil and other energy transportation. The policy makers of China and other countries should be considered this rout for the future energy business.

5) Optimum energy should be adopted by the authorities of the partner countries for reducing global risk. The authority should focus on the opportunity and sustainability of energy business instead of passive risk aversion.

6) Information channel should be established to provide update information to buyer and seller company for minimizing risk through prior risk warning. Information channel can minimize the risk and optimize the energy business under OBOR strategic context.

7) All the potential risk can be minimized by strengthening current rules, regulations, legislation and policy related to global energy business. Business-friendly policy legislation can easily minimize risk and maximize global energy business under OBOR. It can be done through bilateral discussion considering the investment protection mechanism.

8) Insurance system for foreign investment should be launched through bilateral, multilateral, and regional agreement for smooth running of energy business and minimizing risk associated with energy business.

\section{Conclusion}

This study analyzes the existing energy business conditions among OBOR partner countries and reveals that OBOR strategic context is more favorable for all 
partner countries in terms of minimizing risk, regular demand and supply, infrastructure, mutual cooperation and future relationship. This study uses secondary sources extensively and develops a conceptual framework for cross-border energy business under OBOR strategic context. It has also identified six major risks with some indicators for energy business within OBOR partner countries. It suggests that a strong policy measure, business-friendly corridor, infrastructure development, favorable flexible rules and regulations, global risk prevention team comprising the foreign ministries of partner countries and foreign investment insurance system should be introduced in OBOR strategy for smooth running the energy business. This study also suggests that further study is necessary to determine the impact and energy security of OBOR initiative on energy business.

\section{References}

[1] Crompton, P. and Wu, Y. (2005) Energy Consumption in China: Past Trends and Future Directions. Energy Economics, 27, 1-20.

https://doi.org/10.1016/j.eneco.2004.10.006

[2] Cunningham, E.A. (2015) The State and the Firm: China's Energy Governance in Context. Global Economic Governance Initiative Working Paper, 1-10.

[3] Wu, X.F. and Chen, G.Q. (2017) Energy Use by Chinese Economy: A Systems Cross-Scale Input-Output Analysis. Energy Policy, 108, 81-90.

https://doi.org/10.1016/j.enpol.2017.05.048

[4] Yang, X.J., Hu, H., Tan, T. and Li, J. (2016) China's Renewable Energy Goals by 2050. Environmental Development, 20, 83-90. https://doi.org/10.1016/j.envdev.2016.10.001

[5] Duan, F., Ji, Q., Liu, B.Y. and Fan, Y. (2018) Energy Investment Risk Assessment for Nations along China's Belt \& Road Initiative. Journal of Cleaner Production, 170, 535-547. https://doi.org/10.1016/j.jclepro.2017.09.152

[6] EIA (Energy Information Administration) (2015) China. Energy Information Administration.

[7] Mitrovic, D. (2018) China's Belt and Road Initiative: Connecting and Transforming Initiative. In: Y. C. et al., Ed., The Belt \& Road Initiative in the Global Arena, 17-35.

[8] Sheu, J.B. and Kundu, T. (2017) Forecasting Time-Varying Logistics Distribution Flows in the One Belt-One Road Strategic Context. Transportation Research Part E: Logistics and Transportation Review, xxx, 1-18. https://doi.org/10.1016/j.tre.2017.03.003

[9] Wu, K. (2014) China's Energy Security: Oil and Gas. Energy Policy, 73, 4-11.

[10] Shao, Y., Qiao, H. and Wang, S. (2017) What Determines China's Crude Oil Importing Trade Patterns? Empirical Evidence from 55 Countries between 1992 and 2015. Energy Policy, 109, 854-862. https://doi.org/10.1016/j.enpol.2017.05.063

[11] Wang, L. (2016) China's Crude Oil and Natural Gas Industry. In: The Oil \& Gas Conference, Denver, Colorado, 1-22.

[12] Tang, B.J., Song, X.T. and Cao, H. (2018) A Study on Overseas Oil and Gas Investment to Avoid the Risk of the Changes in Tax Policies: A Case in China. Journal of Petroleum Science and Engineering, 160, 35-46. https://doi.org/10.1016/j.petrol.2017.10.031 
[13] Sarker, M.N.I. (2017) An Introduction to Agricultural Anthropology: Pathway to Sustainable Agriculture. Journal of Sociology and Anthropology, 1, 47-52.

[14] Sarker, M.N.I. and Jie, Z. (2017) Social Security for Vulnerable Groups in Bangladesh on Government Perspective: Contribution of Research Leader. Journal of Public Policy and Administration, 1, 1-9.

[15] Liu, C., Kuang, Y., Huang, N. and Liu, X. (2014) An Empirical Research on Evaluation of Low-Carbon Economy in Guangdong Province, China: Based on "Production, Life, and Environment. Low Carbon Economy, 5, 139-152.

https://doi.org/10.4236/lce.2014.54015

[16] Yang, B. (2017) China's Low-Carbon Economy Development and Carbon Finance Market Supervision Mechanism. Low Carbon Economy, 8, 97-105. https://doi.org/10.4236/lce.2017.84008

[17] UHRP (Uyghur Human Rights Project) (2016) End of the Road: One Belt, One Road and the Cumulative Economic Marginalization of the Uyghurs.

[18] Wang, H. (2015) One Belt One Road Strategy: Energy Transit Risks. 1-3.

[19] Sun, Z., Wang, Y. and Dun, F. (2017) Estimating Oil/Natural Gas Trade Competitiveness and Cooperation Potential of Main OROB Countries: Perspective of Industry Chains. IAEE Singapore 2017, 86-87.

[20] Sternberg, T., Ahearn, A. and Mcconnell, F. (2017) Central Asian "Characteristics" on China's New Silk Road: The Role of Landscape and the Politics of Infrastructure. Land, 6, 55. https://doi.org/10.3390/land6030055

[21] Pan, L., Liu, P. and Li, Z. (2017) A System Dynamic Analysis of China's Oil Supply Chain: Over-Capacity and Energy Security Issues. Applied Energy, 188, 508-520. https://doi.org/10.1016/j.apenergy.2016.12.036

[22] Neill, D.C.O. (2017) One Belt, One Road, One Regime Type: The Limits of Chinese Influence in Developing States. ISA International Conference 2017, 1-32.

[23] Nalbantoglu, C. (2017) One Belt One Road Initiative: New Route on China's Change of Course to Growth. Open Journal of Social Sciences, 5, 87-99. https://doi.org/10.4236/jss.2017.51007

[24] Zheng, Y. (2017) Evaluating China's Oil Security and Overseas Oil Investment. American Journal of Industrial and Business Management, 7, 959-972. https://doi.org/10.4236/ajibm.2017.78069

[25] Liedtke, S. (2017) Chinese Energy Investments in Europe: An Analysis of Policy Drivers and Approaches. Energy Policy, 101, 659-669. https://doi.org/10.1016/j.enpol.2016.09.037

[26] Chen, J., Wang, N., Tang, H., Li, J. and Xiong, B. (2016) Impact of Sustained Low Oil Prices on China's Oil \& Gas Industry System and Coping Strategies. Natural Gas Industry B, 3, 181-186. https://doi.org/10.1016/j.ngib.2016.05.001

[27] Aloui, R., Gupta, R. and Miller, S.M. (2016) Uncertainty and Crude Oil Returns. Energy Economics, 55, 92-100. https://doi.org/10.1016/j.eneco.2016.01.012

[28] Kang, W., Ratti, R.A. and Vespignani, J.L. (2017) Oil Price Shocks and Policy Uncertainty: New Evidence on the Effects of US and Non-US Oil Production. Energy Economics, 66, 536-546. https://doi.org/10.1016/j.eneco.2017.01.027

[29] Wang, J., Feng, L., Zhao, L. and Snowden, S. (2013) China’s Natural Gas: Resources, Production and Its Impacts. Energy Policy, 55, 690-698.

https://doi.org/10.1016/j.enpol.2012.12.034

[30] Sinogasenergy (2016) Oil \& Gas Council China Summit September 2016. 
[31] Wu, K. (2008) China's Overseas Oil and Gas Investment: Motivations, Strategies, and Global Impact. Oil, Gas \& Energy Law, 6, 1-9.

[32] China Energy Group (2014) Key China Energy Statistics 2014. Lawrence Berkeley National Laboratory. http://eetd.lbl.gov/publications/key-china-energy-statistics-2014

[33] Edwards, S., Ishaq, O. and Johnsen, O. (2011) Oil and Gas 2030. IBM Global Business Services, Executive Report. http://www.theterritory.com.au/index.php?menuID=163

[34] Dent, C.M. (2015) China's Renewable Energy Development: Policy, Industry and Business Perspectives. Asia Pacific Business Review, 21, 26-43. https://doi.org/10.1080/13602381.2014.939892

[35] Thomson, E. and Boey, A. (2015) The Role of Oil and Gas in China's Energy Strategy: An Overview. Asia Pacific Business Review, 21, 10-25. https://doi.org/10.1080/13602381.2014.939890

[36] Wang, Q., Zhu, Y. and Wang, Y. (2017) The Effects of Oil Shocks on Export Duration of China. Energy, 125, 55-61. https://doi.org/10.1016/j.energy.2017.02.101

[37] Kang, W., Perez de Gracia, F. and Ratti, R.A. (2017) Oil Price Shocks, Policy Uncertainty, and Stock Returns of Oil and Gas Corporations. Journal of International Money and Finance, 70, 344-359. https://doi.org/10.1016/j.jimonfin.2016.10.003

[38] Zhang, W., Yang, J., Zhang, Z. and Shackman, J.D. (2017) Natural Gas Price Effects in China Based on the CGE Model. Journal of Cleaner Production, 147, 497-505. https://doi.org/10.1016/j.jclepro.2017.01.109

[39] Zhang, G., Li, B., Zheng, D., Ding, G., Wei, H., Qian, P. and Li, C. (2017) Challenges to and Proposals for Underground Gas Storage (UGS) Business in China. Natural Gas Industry, 37, 153-159.

[40] Liu, Y. and Ma, L. (2016) Impacts of Low Oil Price in China and the World Natural Gas Industry Chain. Natural Gas Industry B, 3, 493-503. https://doi.org/10.1016/j.ngib.2017.02.010

[41] Li, Q., Cheng, K. and Yang, X. (2015) Impacts of Oil Price Shocks on the Returns of China's Listed Oil Companies. Energy Procedia, 75, 2604-2609. https://doi.org/10.1016/j.egypro.2015.07.329

[42] Jiang, Z., Wang, F., Duan, Y. and Zhou, J. (2016) China's Gas Market under New Situations: Trends and Countermeasures-Taking Sichuan and Chongqing Gas Provinces as an Example. Natural Gas Industry B, 3, 187-194. https://doi.org/10.1016/j.ngib.2016.05.002

[43] Yang, X., Tong, Q. and Ou, X. (2014) Analysis of Technical Energy Conservation Potential of China's Energy Consumption Sectors. Open Journal of Energy Efficiency, 3, 93-97. https://doi.org/10.4236/ojee.2014.34010

[44] Burger, S.P. and Luke, M. (2017) Business Models for Distributed Energy Resources: A Review and Empirical Analysis. Energy Policy, 109, 230-248. https://doi.org/10.1016/j.enpol.2017.07.007

[45] Meidan, M. (2016) The Structure of China's Oil Industry: Past Trends and Future Prospects. OIES Paper.

https://www.oxfordenergy.org/wpcms/wp-content/uploads/2016/05/The-structureof-Chinas-oil-industry-past-trends-and-future-prospects-WPM-66.pdf

[46] Shaikh, F., Ji, Q. and Fan, Y. (2016) Prospects of Pakistan-China Energy and Economic Corridor. Renewable and Sustainable Energy Reviews, 59, 253-263. https://doi.org/10.1016/j.rser.2015.12.361 
[47] BP (2017) BP Energy Outlook Energy 2017. BP Statistical Review of World Energy.

[48] Lai, H., O’Hara, S. and Wysoczanska, K. (2015) Rationale of Internationalization of China's National Oil Companies: Seeking Natural Resources, Strategic Assets or Sectoral Specialization? Asia Pacific Business Review, 21, 77-95.

https://doi.org/10.1080/13602381.2014.939896

[49] Abudureyimu, A. and Han, Q. (2014) Clean Energy Development of Silk Road Economic Belt in Xinjiang. Applied Mechanics and Materials, 521, 846-849. https://doi.org/10.4028/www.scientific.net/AMM.521.846

[50] He, P., Ng, T.S. and Su, B. (2017) Energy-Economic Recovery Resilience with Input-Output Linear Programming Models. Energy Economics, 68, 177-191. https://doi.org/10.1016/j.eneco.2017.10.005

[51] Diaz, E.M. and de Gracia, F.P. (2017) Oil Price Shocks and Stock Returns of Oil and Gas Corporations. Finance Research Letters, 20, 75-80. https://doi.org/10.1016/j.frl.2016.09.010

[52] Downs, B.E., Herberg, M.E., Kugelman, M., Brady, C.W., Rindlaub, J.V, Fargo, W., et al. (2017) Asia's Energy Security. 1-8.

[53] Ekman, A., Nicolas, F. and Seaman, J. (2017) Three Years of China's New Silk Roads. 1-5. 